\title{
T-C Education Reform of Marketing Based on Six Teaching Points
}

\author{
Xin Zhao ${ }^{a}$, Qiyong $\mathrm{He}^{\mathrm{b}}$ and Jia Zuo ${ }^{\mathrm{c}}$ \\ Chengdu Neusoft University, Chengdu 611844, China \\ a380035698@qq.com, b21228048@qq.com, c5770524@qq.com
}

Keywords: Six teaching points, T-C, Marketing, Teaching reform.

\begin{abstract}
Six teaching points" is put forward in the implementation of TOPCARES-CDIO teaching reform by Chengdu Neusoft University, which is to optimize teaching process and improve teaching quality. Based on the advanced concept of "six teaching points ", this paper carries out a T-C teaching reform on marketing, redesigns the curriculum objectives, contents and methods, and clarifies the teaching team, teaching conditions and teaching effect. Through this teaching reform practice, we have greatly improved the students' practical ability and the grasping degree of the theoretical knowledge of the course, and we will further improve the $\mathrm{T}-\mathrm{C}$ teaching reform of marketing course.
\end{abstract}

\section{Related Concepts of T-C}

T-C is the abbreviation of TOPCARES-CDIO, which is based on the CDIO engineering education mode of Dalian Neusoft University, Chengdu Neusoft University and Nanhai Neusoft University, The main content of the CDIO consists of the following four aspects: C-Conceive, D-Design, I-Implement, and O-Operate, in combined with the university's own situation, finally formed the unique TOPCARES-CDIO eight elements capability index system. The eight elements capability index system has been upgraded from T-C1.0 to T-C2.0 after several years' practice and refining of the three above-mentioned universities. The latest version of the eight elements capability index is as follows: T- Technical Knowledge and Reasoning, O-Open thinking and innovation, P-Personal and Professional Skills, C- Communication and Teamwork, A- Attitude and Manner, R- Responsibility, E- Ethical Values, S- Social contribution by application practice.

\section{What's the "six teaching points"}

"Six teaching points" is the decomposition of the TOPCARES-CDIO, which in order to optimize the teaching process in implementation of the practice of TOPCARES-CDIO teaching reform of the Chengdu Neusoft University. It can be used not only as the general guidance of major construction, but also the design of specific courses and teaching reform.

The "six teaching points" are divided into six aspects: teaching aim, teaching contents, teaching methods, teaching staff, teaching conditions and teaching quality.

\section{The Design of T-C Teaching Reform Based on "Six Teaching Points" in Marketing}

\subsection{Teaching Aim}

Teaching aim is the key of the whole curriculum teaching reform. Only by figuring out the teaching objectives can we finally ensure that the ability of the training meets the actual needs of the society and enterprises, if there is a deviation in the teaching objectives, all the subsequent teaching processes are done in vain.

According to professional research and return visit to graduates of the teachers of marketing course group during the summer holiday, finally we drew a conclusion that the first level ability indicators of T-C for marketing course are T, O, C, E and S, on this basis, we define the 6 second level ability indicators and 7 third level ability indicators, as shown in Figure 1; and the 13 fourth level ability indicators are set correspond to specific curriculum content, as shown in Table 1. 


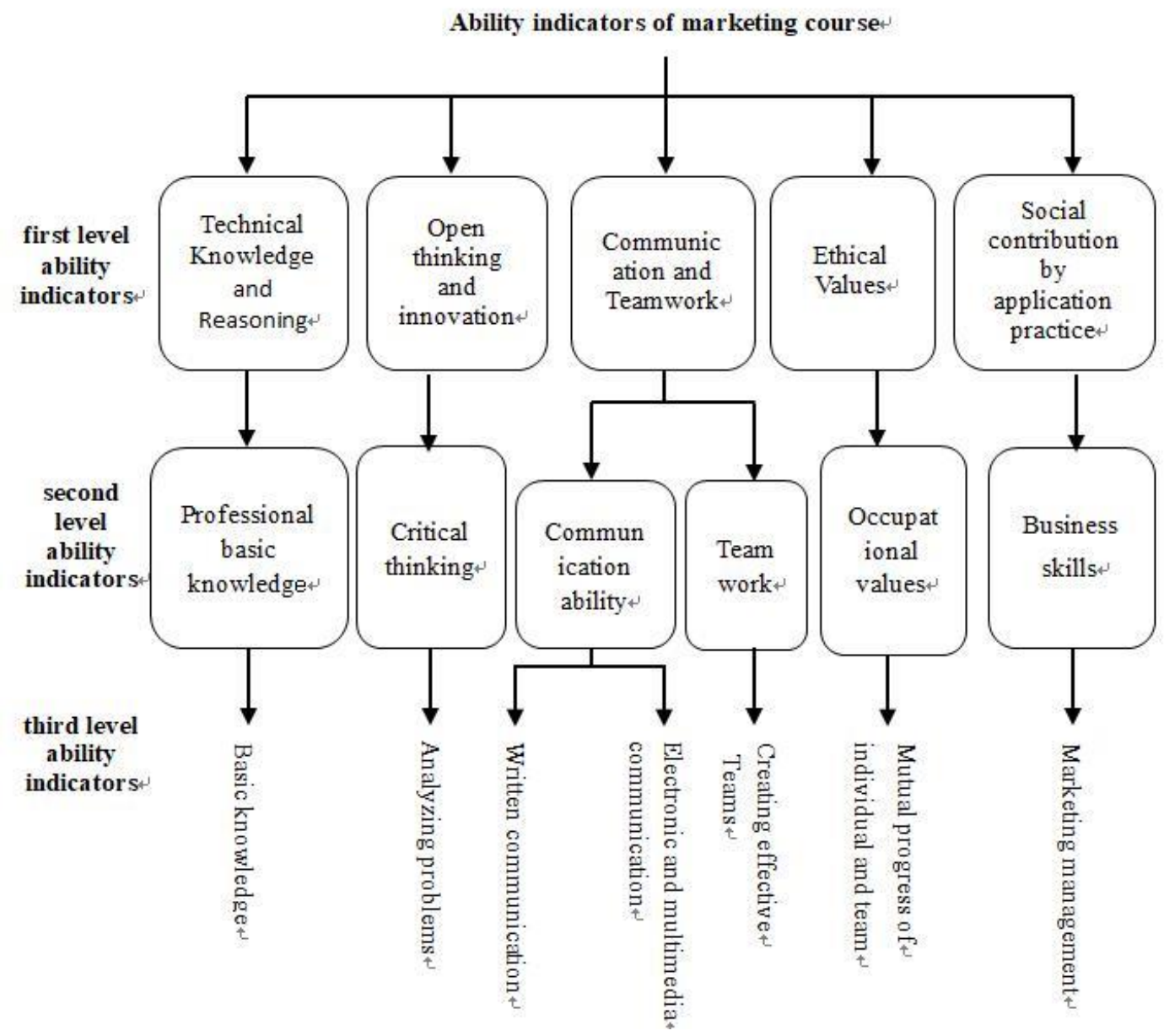

\subsection{Teaching Contents}

Fig. 1 Design of teaching goal for marketing

After determining the teaching aim, it is necessary to design the teaching contents of the course according to the determined teaching aim. The teaching contents of marketing course is set up according to the CDIO engineering teaching model, which breaks the traditional teaching system of marketing, and is more convenient for students to understand and grasp. Through the reform, the theoretical and practical class hours of marketing have been changed from the original 48 class hours and 16 class hours to 32 class hours each, while the total class hours of 64 hours have remained unchanged. The specific teaching contents are shown in Table 1.

\subsection{Teaching Methods}

There are many common teaching methods of marketing courses, the most commonly used is the case teaching method, but the traditional case teaching method only corresponds the scattered cases to the various knowledge points of marketing. Although it helps students to understand the knowledge on the textbooks, the unsystematic cases cannot help students to a deeper understanding of the entire marketing processes.

In this T-C teaching reform, in order to make students have a more comprehensive and systematic understanding of marketing, the teachers of the course group firstly determined the " integration of teaching and competition" teaching mode, selecting the national university students oriented "innovation, creativity, Entrepreneurship" Challenge organized by the Ministry of Education (after abbreviated "three creation" Challenge), combining with the course teaching, then designed the teaching method of the course according to the entries needed to submit in the competition-the entrepreneurial plan, and finally, determined to adopts the teaching method of combining scenario simulation with project teaching. That is, the course adapted a through-the-road project — forming teams for entrepreneurship practice. At the beginning of the course, the students form a entrepreneurial team of 4-6 people and set up a company, each student take charge of CEO, CFO and 
other positions through the scenario simulation, each company determine the target product, the target market and target customers and draft their own products 4P sales strategy through the marketing environment analysis and market research, and then complete the integrated entrepreneurial plan and put into practice. At the same time as completing the teaching and learning process in the classroom, the final entries that needed to be submitted for the "three creation" Challenge have also been completed.

Table 1 Design of Teaching contents of Marketing based on CDIO

\begin{tabular}{|c|c|c|c|c|}
\hline \multirow{2}{*}{$\begin{array}{l}\text { CDIO Engineering } \\
\text { Teaching Model }\end{array}$} & \multirow{2}{*}{$\begin{array}{l}\text { Theoretical Teaching } \\
\text { content (Class hours) }\end{array}$} & \multicolumn{2}{|c|}{ Practical Teaching Contents } & \multirow{2}{*}{$\begin{array}{l}\text { Fourth Level ability indicators of } \\
\text { T-C }\end{array}$} \\
\hline & & Project & Task(Class hours) & \\
\hline \multirow[b]{4}{*}{ Conceive } & \multirow{4}{*}{$\begin{array}{c}\text { Introduction of } \\
\text { marketing(2) } \\
\text { Marketing } \\
\text { environment(4) } \\
\text { Consumer purchasing b } \\
\text { ehavior(2) } \\
\text { STP strategy(4) }\end{array}$} & \multirow[b]{4}{*}{$\begin{array}{l}\text { Project 1: Preparatory tas } \\
\text { ks before } \\
\text { Entrepreneurship }\end{array}$} & $\begin{array}{l}\text { Task 1: Set up a team of innovat } \\
\text { ion and entrepreneurs }(2)\end{array}$ & \multirow{4}{*}{$\begin{array}{l}\text {-Good command of the basic } \\
\text { Theory } \\
\text { of Marketing } \\
\text {-Set up an entrepreneurial team } \\
\text {-Distinguish the roles and responsi } \\
\text { bilities of the team } \\
\text {-Able to analyze the marketing } \\
\text { environment } \\
\text {-Able to analyze the consumer } \\
\text { behavior } \\
\text {-Able to subdivide markets and sel } \\
\text { ect target markets }\end{array}$} \\
\hline & & & $\begin{array}{l}\text { Task 2: Analyze marketing envir } \\
\text { onment(2) }\end{array}$ & \\
\hline & & & $\begin{array}{c}\text { Task 3: Research consumer } \\
\text { behavior(4) }\end{array}$ & \\
\hline & & & $\begin{array}{l}\text { Task 4: Market positioning and } \\
\text { target consumer choosing(4) }\end{array}$ & \\
\hline \multirow{2}{*}{ Design } & \multirow{2}{*}{$\begin{array}{c}\text { SWOT theory(2) } \\
\text { Product strategy(2) } \\
\text { Pricing strategy(2) } \\
\text { Channel strategy(2) } \\
\text { Promotional strategy(2) }\end{array}$} & \multirow{2}{*}{ Project 2: Business plan } & Task 1: SWOT analysis(4) & -Able to perform SWOT analysis \\
\hline & & & Task 2: Draft a 4P strategy(8) & $\begin{array}{l}\text {-Able to formulate products, price } \\
\text { s, } \\
\text { channels, promotion strategies }\end{array}$ \\
\hline Implement & $\begin{array}{l}\text { Writing skills of Entrep } \\
\text { reneurial Plan(4) }\end{array}$ & $\begin{array}{l}\text { Project 3: Write project } \\
\text { plan }\end{array}$ & $\begin{array}{l}\text { Task 1: Write Entrepreneuria } \\
\qquad \operatorname{plan(4)}\end{array}$ & $\begin{array}{c}\text {-Able to write Entrepreneurial Plan } \\
\text { - Able to use PPT and other tools t } \\
\text { o demonstrate and report the } \\
\text { marketing } \\
\text { work and written reports }\end{array}$ \\
\hline \multirow[t]{2}{*}{ Operate } & \multirow{2}{*}{$\begin{array}{l}\text { Advertising design(2) } \\
\quad \text { Sales skill(4) }\end{array}$} & \multirow{2}{*}{$\begin{array}{l}\text { Project 4: Operation of } \mathrm{t} \\
\text { he Entrepreneurial Proje } \\
\text { ct }\end{array}$} & $\begin{array}{l}\text { Task 1: Advertising design and } \\
\text { delivery of Project products } \\
\text { (4+After class) }\end{array}$ & \multirow{2}{*}{$\begin{array}{c}\text {-Able to design advertisement } \\
\text {-Able to select advertising channel } \\
\text { correctly } \\
\text {-Grasp sales skills }\end{array}$} \\
\hline & & & $\begin{array}{c}\text { Task 2: Complete sales } \\
\text { business(After class) }\end{array}$ & \\
\hline
\end{tabular}

\subsection{Teaching Staff}

Excellent teachers are the guarantee of teaching quality. Through nearly two years of hard work, this course has established a triune and multi-mentioned teaching team: the course content is taught mainly by double-professionally-titled teachers; and introduction of industry, enterprise experts of marketing, to explain the operational skills of entrepreneurial plan and other practical part to students. At the same time, we introduce the students who have good appearance on marketing courses or won the award in the last several "three creation" Challenge into the classroom to introduce the successful experience to the students who are studying in the marketing course. Triune teaching team had laid a solid foundation for marketing course teaching and studying.

\subsection{Teaching Conditions}

The training of practical ability needs to be carried out in a real or simulated environment. Chengdu Neusoft University is equipped with 3A (Anytime, Anywhere, Anyway) practical teaching platform according to the requirements of TC teaching reform for practice environment, and adapted e-learning style, which students can work at anytime, anywhere, in any way to participate learning course in the marketing of virtual simulation environment. It perfectly combined with the scenario simulation teaching methods, and greatly enhanced the students' practical ability. 


\subsection{Teaching Quality}

Whether a teaching reform of a course success or not, it depends on the final test, that is, need to see the final teaching effect. After two years of T-C teaching reform for marketing, we has achieved good effects.

In terms of theoretical teaching, compared with the students before the teaching reform, the final exam average score of the marketing course of the current student increased from 60.52 to 68.98 , and the overall raised about $14 \%$, which fully explained that the $\mathrm{T}-\mathrm{C}$ teaching reform based on "six teachings" is more conducive to students' understanding and grasping the knowledge of marketing textbooks.

In practice teaching, the quality of the entrepreneurial plan submitted by students is obviously improved. In 2017, a total of 12 teams won awards above the provincial level in the national "three creation" Challenge, and $80 \%$ students of the 12 teams have studied marketing courses and completed the entries through the course, one of the participating teams is even won the second prize of the national competition in the "three creation" Challenge.

\section{Summary}

The National Conference on Education held on July 2010 by the CPC Central Committee and the State Council issued "the Outline of the national medium and long-term education reform and development plan (in 2010-2020), which put forward "improvement of quality as the core task of educational reform and development". And the primary goal of T-C teaching reform and curriculum design is to improve the teaching quality of the curriculum, therefore, curriculum design is the core part of every teacher preparing lessons before class. The T-C teaching reform based on "six teaching points" is the guarantee of improving the quality of the curriculum. Fully understanding the contents of "six teaching points" and the concept of T-C teaching reform can effectively improve the teaching quality of the course.

\section{References}

[1]. Guihua Kang. Implementing the TOPCAERS-CDIO educational and teaching reform with the optimization of the "six teaching points" innovative teaching process. Chinese adult education. Vol. 4(2015) No.4, p. 126-128.

[2]. Zhenhan $\mathrm{Yu}$, Haolei Yang, et al. Study on the training Model of Cold Chain Logistics talents under the concept of CDIO. Logistics Technology. Vol. 7(2014) No.7, p. 390-392.

[3]. Yong Yang, Jingliang Jiang, Dexiang Wang, et al. A new Pattern of CDIO Engineering Education and Application in Mechanical Principle Course. International Conference on Humanities and Social Science Research. Guangzhou, 2013-12-30, p. 489-492.

[4]. Xin Guo, Jifang Zhai. The Reform and Innovation of Using CDIO for Reference Taking Dalian Neusoft Institute of Information as an Example. International Conference on Educational technology and Information systems. Sanya, 2013-6-21, p. 561-564.

[5]. Lin Tong, Chen Wang, Dejun Tang, et al. SOVO Practice Teaching Base Reform Based on TOPCARES-CDIO. 2010 Third International Conference on Education Technology and Training (ETT 2010). Wuhan, 2010-11-27, p. 61-64. 